\title{
Pasteur Institute celebrates centenary - and so do NIH
}

Paris

THE renowned Pasteur Institute in Paris opened its centenary celebrations last week with a five-day international symposium on molecular biology and infectious diseases. More than 300 researchers and physicians, including eight Nobel prizewinners, attended the conference, which was opened by the French President, François Mitterrand, and closed by the Prime Minister, Jacques Chirac.

Other events associated with the celebrations - estimated to have cost its sponsors around FF10 million (\$1.6 million) - include a retrospective exhibition at the institute, a 50-minute television documentary film, a photographic exhibition at the national science and industry museum and the creation of a permanent historical exhibition at the Pasteur station on the Paris metro.

The four themes of the symposium viral diseases, bacterial diseases, parasitic diseases and host defence mechanisms reflected developments over the past century in microbiology as a whole and in the work of the institute in particular.

Many 'Pastorians' found a symbol of the century's progress in microbiology in the presentation at the symposium, by its youngest speaker, Noël Tordo, of the complete genome of the rabies virus. The institute was founded in 1887 after a fundraising drive provided Louis Pasteur with an institution in which to develop the rabies vaccine he had successfully demonstrated two years before.

Regulations covering the release of recombinant microorganisms could, however, preclude the use of new rabies vaccines being tested at the institute as part of this campaign.

The Pasteur Institute has remained an independent foundation, despite a difficult time in the 1970 s when the government was called upon to provide extra funds. Since 1976, 47 per cent of the institute's FF500 million annual budget comes from the state. In addition, the state pays for salaries of 140 of the institute's 500 staff researchers attached to the Centre National de la Recherche Scientifique (CNRS). Thirteen of the institute's research units (include Luc Montagnier's viral oncology unit) are associated with the CNRS.

More than half the institute's budget is made up of a combination of fund-raising (14 per cent), royalties from its industrial subsidiaries, Pasteur Vaccins and Diagnostics Pasteur (10 per cent), and from its own resources ( 29 per cent). The creation of a separate commercial infrastructure to exploit the institute's discoveries began in the 1970 s and replaced the previous "cot- tage industry' approach to vaccine preparation in institute laboratories.

In his closing address last Friday, Chirac tried hard to find a way to make it seem as if his government cares for fundamental research - most public sector budgets for 1988 will either be cut or, effectively, remain static relative to last year, although medical research is less affected (see Nature 329, 380; 1987). Chirac referred to the FF100 million additional grant recently released for AIDS (acquired immune deficiency syndrome) research part of which will go to the institute - but had to look back to the era of President Charles de Gaulle for other evidence of Republican legacies to medical research. Celebrations will continue into Novem- ber and hopes are that additional funds will be attracted as a result of the high public profile of the institute. Peter Coles - On the other side of the Atlantic, the National Institutes of Health (NIH) are in the midst of the concluding celebrations to their own centennial year. NIH began rather more modestly than the Pasteur Institute as a one-room Hygienic Laboratory on Staten Island, New York, but have grown into a massive complex of laboratories centred on the campus at Bethesda, Maryland, and employing a total of 3,500 scientists. Their $\$ 6$ million budget supports the research of another 20,000 scientists at 1,300 universities throughout the United States. Between them, NIH grantholders have won close to 60 Nobel prizes.

The history and future of $\mathrm{NIH}$ will be the subject of two special articles in next week's Nature from former NIH directors Robert Q. Marston and Donald S. Fredrickson.

\section{British government crushes hopes for extra space funds}

\section{London}

THE mood of cautious optimism within the British space community, which believed that there was a real chance of the government increasing its investment in space research before next month's ministerial meeting of the European Space Agency (ESA), has been destroyed by the announcement by $\mathrm{Mr}$ Kenneth Clarke, the Minister for Trade and Industry, that no more money will be forthcoming.

Speaking on television at the weekend, Clarke described ESA as a "hugely expensive club" with over-ambitious pro-

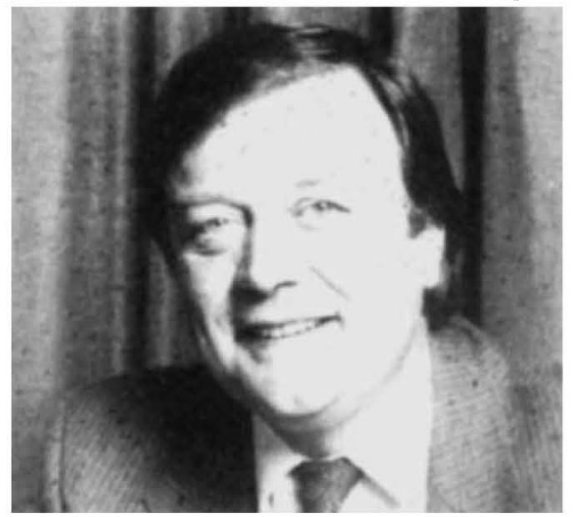

Kenneth Clarke - no more money.

grammes. The government would not be increasing its $£ 112$ million space budget, three-quarters of which is spent through ESA. When ESA ministers meet on 9 and 10 November in The Hague, they are expected to ratify a major infrastructure programme for the next decade, requiring at least a doubling of the present budget.

The timing of Clarke's announcement has angered and puzzled the space community. It had been widely understood that the government's newly created Advisory Council on Science and Technology (ACOST) would review Britain's space programme before the ESA meeting and make recommendations to the government. After the first meeting of ACOST on 29 September, its chairman, Sir Francis Tombs, said that "preliminary consideration" had been given to national priorities for space research. Tombs said that a "round-table discussion" would be held between ACOST and representatives of the space community. It was widely assumed that this meeting, scheduled for later this month, would enable ACOST to decide if Britain should increase its spending on space, and advise the government accordingly.

Since the prime minister, Mrs Margaret Thatcher, announced in the House of Commons on 23 July that the government would not increase its space budget "for the time being" (see Nature 328, 467; 1987), Britain's space community has been in turmoil.

Roy Gibson, BNSC's director-general, resigned on 4 August. Later that month the government bowed to pressure from ESA and industry by producing an extra $£ 4$ million to enable British companies to continue pre-development work on ESA projects until the November meeting. Given this encouraging sign, the British space community refused to accept that all was lost, pinning its hopes on ACOST.

The space community seems to have been prompted by its own enthusiasm into believing that the government was on the verge of reversing its earlier decision. $\mathrm{Mr}$ Clarke has put paid to that.

Simon Hadlington 